\title{
The Malawi 2002 food crisis: the rural development challenge ${ }^{1}$
}

\author{
Andrew Dorward and Jonathan Kydd*
}

\begin{abstract}
A B S T R A C T
The recent food crisis in Malawi has drawn stark attention to the failures of development policies over the last forty years to create wealth and develop a robust economy or the markets on which such an economy must depend. Current market liberalisation policies have achieved at best mixed success in addressing the generic problems inhibiting smallholder agricultural development: low returns to farmers' and service providers' investments, with high risks from natural shocks, price variations, coordination failure and opportunistic behaviour. Postindependence institutional mechanisms in Malawi were more successful in addressing some of these problems, in particular those of coordination risk, although external and internal difficulties led to increasing costs and declining effectiveness of these mechanisms, and to their collapse. They do provide, however, important lessons about the different failures of both market intervention and market liberalisation policies. We suggest and discuss a set of critical elements needed for economic development and wealth creation in poor rural areas, and propose four basic principles to guide the search for, and design and implementation of, effective rural development strategies and policies.
\end{abstract}

\section{N T R O D U C T I O N}

Along with a number of other southern Africa countries, Malawi entered 2002 in acute crisis with a looming famine. The causes of this crisis may appear more obvious in other countries, such as war-torn Angola and the Democratic Republic of the Congo, but we need to dig deeper to ask why relatively mild weather shocks (as compared, for example, with the I99I/92 drought) triggered such a crisis. Devereux (2002) has provided an excellent and detailed examination of the processes and immediate causes of the food shortages in Malawi in early 2002, but as he recognises, there remain underlying questions regarding the vulnerability of the rural economy to production shocks, and the institutional capacity (of government,

* Both at the Centre for Development and Poverty Reduction, Imperial College London, Wye Campus. 
markets and other actors) to respond to and manage the effects of such shocks. This paper addresses these questions, focusing on the situation in Malawi. Despite the single country focus of this discussion, we suggest that our analysis is relevant to the process of development in poor rural areas in other parts of Africa and in South Asia. However, in drawing lessons for other areas, due attention needs to be paid to differences in, for example, agricultural technologies and opportunities, local and national institutions, infrastructure and communications, and non-farm opportunities. Our analysis assumes, in particular, the existence of more intensive and productive agricultural technologies which suit local agro-ecology, even if their adoption is constrained by market and institutional failures. We suggest that more intensive maize technologies can fill this role in most of Malawi, but recognise that, for more arid areas in southern Africa, this is not the case.

Malawi is a very poor country: ${ }^{2}$ the national poverty rate was estimated at $65 \%$ in 1998, and gross national income per capita in 2002 was estimated at \$US i6o, down from \$US 200 in 1990. The economy is remarkably open: trade was $72 \%$ of national income in 2002, compared to $57 \%$ in i99o. There is a high dependence on foreign aid, at \$US 38 per capita in 200I, although aid flows have fallen significantly in very recent years as donors have been unable to fully disburse committed funds (World Bank 2003), because government has fallen out of compliance with mutually agreed strategies. The urbanisation rate is about $15 \%$ and dependence on agriculture, estimated at $39 \%$ of GDP in 2002, is notably high and little changed from an estimated $4 \mathrm{I} \%$ in I 982 . It is thought that agriculture's share in national income has increased in the last five years or so, but this is less a consequence of agricultural growth than a result of continuing contraction in the industrial and service sectors, the latter probably being linked to declining aid disbursements. Presently, the investment rate is pitiful: $9 \%$ of GDP in 2002, compared with $23 \%$ in 1990 . There are a few bright spots in the last decade, with major improvements in primary school enrolment and its gender balance, and substantial falls in infant and under-five mortality (though these are still very high, with the under-five mortality rate falling from 253 to 183 per I, ooo live births between I985 and 200i).

We begin with an examination of generic problems facing poor rural areas in Malawi. Understanding these problems allows us to identify critical issues that need to be addressed. This provides us with an analytical framework to consider ways in which first the post-independence policy regime and then a subsequent liberalisation policy regime have addressed, and then failed to address, these issues. We conclude by asking 
'Where next?', and suggest some principles for formulating new national and rural policies.

GENERIC PROBLEMS AND 'SYSTEMIC INVESTMENT RISKS'

IN POOR RURALAREAS

This section describes in a stylised manner some generic problems facing poor rural areas in Malawi, also widely observed in neighbouring countries, and which impact on the lives of large numbers of people. Recognising the complexity and multiple dimensions of the problems in these areas, and of their causes, discussion focuses on a particular set of problems that increase risks and inhibit productive investments.

Perhaps the defining characteristics of rural areas in Malawi are very low and fragile incomes and consequently market activity based on very small transactions. For a long time the rural economy, and (directly and indirectly) people's livelihoods within that economy, have been dependent upon two principal activities: agriculture and migrant labour remittances and returnee savings (see e.g. Morton 1975; Kydd \& Christiansen 1982). Both of these sectors have faced major setbacks over the last thirty years, and although petty trading activity in rural areas has increased markedly in recent years (see e.g. Orr \& Orr 2002), this is mainly a response to the decline of traditional sources of income rather than to a growing local consumer market, and monetisation in the rural economy remains very low (Ellis et al. 2002).

Recent statistics on smallholder production are controversial, with some sources suggesting that agriculture has been growing at a tremendous pace (for example at over $7 \%$ per annum in the I99os, World Bank 200i), based largely on a (conjectural) explosion of cassava production. These estimates are not credible (although unfortunately they frequently crop up in literature on Malawi), but there is continuing debate about some growth in root crops (cassava and sweet potatoes). It can be said with reasonable certainty that smallholder maize production has stagnated. Meanwhile smallholder production of burley tobacco and minor cash crops (such as paprika, birds eye chillies and pigeon peas) has increased (see e.g. Orr \& Mwale 200I), but these are grown by a minority of farming households. Meanwhile commercial estate agriculture is in crisis, with very few crops in which it is able to make profits. ${ }^{3}$ Maize is the dominant food crop and current stagnation in maize production contrasts with, and is a regression from, an earlier 'emerging green revolution' with rapidly expanding growth in smallholders' fertiliser use and hybrid maize production in some areas in the I980s (Carr I997; Heisey \& Smale 1996). 
Migrant labour opportunities had not only been available internationally, but had developed rapidly in the domestic economy in the I970s with the growth of tobacco estates (Kydd \& Christiansen I982). Both international and domestic labour migration have been subject to differing combinations of long-term declines and recent shocks, as a result of varied processes which included: opening of previously protected domestic industries to regional and international competition; declining commodity prices; a switch from estate to smallholder burley tobacco production (as discussed in note 2); failures in parastatals and in privatisation processes; political instability; economic mismanagement; lack of investor confidence; and tightening of controls on international migration. The result is declining opportunities for rural households to find jobs elsewhere, and, for those households with members in employment, reductions in job security, net incomes and ability to save and remit incomes.

A third major source of income in rural areas that is more difficult to quantify is income from direct (i.e. non-agricultural) use of natural resources (e.g. Cavendish 1999 for Zimbabwe). While this undoubtedly remains important in the livelihoods of many rural people in Malawi, particularly in supporting coping strategies of poorer households (e.g. Fisher et al. 2002), it does not provide a basis for expanding incomes and welfare, it is threatened in many places by increasing population densities, and it faces important problems of crowding in and covariant risk with agricultural and agriculturally dependent activities.

One response by rural people to pressure on and declining opportunities from agricultural, migrant and natural resources incomes has been to try to diversify into other activities (Bryceson I999). A major difficulty in the context of the faltering of the traditional drivers of growth has been the lack of opportunities with low capital and skill demands and low risks, apart from petty trading, which has low barriers to entry but offers low returns (see e.g. Ellis et al. 2002).

Concentration of incomes from a narrow range of risky and low productivity activities is exacerbated by poor infrastructure, services and communications, with poor roads and transport services and poor telecommunications, leading to high costs in physical movement of goods and services in and out of rural areas, together with high costs of communication about market opportunities and prices. Education and literacy, particularly among women, also tend to be low, and long-standing problems of very poor health have been exacerbated by the spread of HIV/ AIDS. ${ }^{4}$ Health and education services, meanwhile, are stretched and often underresourced and ineffective, undermined themselves by the impact of 
HIV/AIDS, limited human resources, fiscal constraints, remoteness and often ineffective management.

The result of the low general level of economic activity, of the risks from lack of diversification, and of poor communications is thin markets, i.e. very low traded volumes of key commodities, manufactures and services (examples of these categories being: agricultural produce, agricultural inputs and agricultural finance). Thin markets are both a cause and a consequence of the fact that while volumes traded are low, the costs and risks of trading are high. Underlying factors include high communication costs, the fact that these high costs are carried by very low volumes, and the combination of low and risk-prone volumes with poor and costly information services, leading to high risks of transaction failure for buyers and sellers. This requires high risk premiums and margins to make it profitable to engage in markets, but these high margins themselves depress demand, and the result is a low level equilibrium trap ${ }^{5}$ and market failure (Dorward et al. 2004). These problems are particularly acute in input, output and financial markets needed for the intensification of seasonal food crop production, notably for maize, the overwhelmingly dominant staple food.

To examine how these problems might be overcome, we need to consider in more detail the particular risks facing rural inhabitants and other investors or potential investors in these rural economies. We identify four basic categories of risk that inhibit productive investments necessary to promote economic growth and wealth creation in poor rural areas: risks of natural shocks; price risks; economic coordination risks; and risks of opportunism. We term the problem that these risks pose the 'systemic investment risks' of poor rural areas, as these areas face a particularly intractable set of development problems due to the high risks that investors face in all four risk categories.

Low levels of financial and physical capital, together with reliance on agriculture and natural resources, make poor rural economies and livelihoods particularly exposed and vulnerable to risks of natural shocks. These may arise from adverse weather (affecting crop yields or damaging physical assets); human, crop or animal disease; or physical insecurity (as a result of crime, political violence or conflict). Where markets are thin and there are poor communications and high transport costs, isolated markets are prone to large price risks when affected by local supply or demand shocks. This may be particularly problematic for food crops which have relatively inelastic demand, and where there are large differences between local import and export parity prices (as is the case for Malawi). There is a long-standing literature on the existence and effects of such risk for poor 
rural livelihoods, and on ways that poor rural people attempt to reduce their exposure to it.

While we recognise the importance of these shocks, our primary focus here is to draw attention to two transaction risks that have not been given enough consideration by development policy analysts. These transaction risks may not be as obvious as the natural shocks and price risks discussed above, but they can nevertheless have devastating effects on the returns to investments, and hence on investment flows. First we consider economic coordination risk, which is the risk of failure of one player's investment due to the possible absence of complementary investments by other players in different stages in the supply chain. In developed economies these risks have been examined in a seminal work by Williamson (1985) and in subsequent new institutional economics writings on transaction costs and contractual arrangements. There has been less work on this problem in developing economies (Jaffee \& Morton I995; Dorward et al. I998).

It is not generally recognised that the problems of specific assets as defined by Williamson are a special case of a more general problem of thin markets which, as argued above, are a systemic problem in poor rural areas. When the returns to an investment are dependent upon complementary actions in a very thin market, any investment is subject to the risk that either no other actor will make the necessary complementary actions (economic coordination risk), or that an actor who could make such actions has an effective monopoly and is able to capture an undue share of the revenue in the supply chain. The latter is an example of the second type of transaction risk that we need to consider, risk of opportunism by other players. Risks of opportunism not only arise where there are thin markets, but may also occur where there are weak institutions protecting contracting parties from opportunism, or where there is strong information asymmetry (for example where the quality of goods or services is difficult for buyers to judge). However, thin markets lead to important additional risks of opportunism.

Economic coordination risks, and associated risks of opportunism, are particularly problematic in poor rural areas, with their very low levels of economic activity, poor transport and thin markets. In the development of markets needed to support more intensive crop production in poor rural areas, for example, there are extensive economic coordination risks facing different investors required in the supply chain: financial service providers, input suppliers, farmers, produce traders and transporters. Thus returns to farmers' borrowings to purchase inputs are dependent on access to inputs (subsequent to borrowing), and on access to produce markets (subsequent to production); returns to financial service providers' 
investment in agricultural lending are dependent on farmers' demand and subsequent repayments (which depend upon input suppliers and produce buyers); returns to input suppliers' investments in stock and marketing systems are dependent on farmers' subsequent access to and uptake of seasonal finance and access to transport services; produce traders' investments in buying systems and purchases are dependent on farm production and access to transport services; and investments in transport services are dependent on demand from input and produce traders and on road maintenance and access. Similarly, the different players face risks of opportunistic behaviour by other players: lenders are at risk from 'strategic default' by farmers; farmers are at risk from low prices offered by maize traders at harvest time (when farmers are desperate for cash) or in remote areas (where farmers have no other sales outlets); farmers are at risk from input sellers supplying poor quality or adulterated inputs, and from use of inaccurate or loaded weights and measures by input or produce traders; farmers and traders with commodities requiring urgent transport may also be vulnerable to opportunistic behaviour by individual transporters or by transporters' cartels.

We have not explored the full range of possible coordination links that exist (we might, for example, also consider the need for extension services to promote input use or crop production, or for law enforcement to prevent theft or loan defaults). Nevertheless, the importance of coordination risk should be apparent, as failure by any one investor in the supply chain (or failure by a sufficient number of farmers to generate breakeven volumes for other parties) will cause their investments to fail. Furthermore, as willingness to invest is determined by expectations of returns, and the returns to investments depend upon investments by others, the returns to investments of all players are subject to each others' expectations of returns. It only takes one investor to withdraw because of perceptions of high risks of shocks, prices, coordination failure or opportunism, for all other investors to lose their shirts. It is important to recognise the critical role of expectations and trust in perceptions of coordination risks.

All these categories of risk lower the productivity of the rural economy by (a) directly lowering the average returns to investment within the economy; (b) distorting investments within the rural economy away from those that maximise expected returns towards those that reduce risks under adverse conditions; and (c) discouraging investments within the rural economy as a result of both reduced expected returns and risk aversion of investors. Overcoming systemic investment risks therefore requires a lowering of risk and a raising of expected secure returns to a level that provides opportunities for productive investments that both promise and 
deliver returns sufficient to attract investors and drive economic growth. Attention therefore needs to be paid to reducing risks from coordination failure; reducing risks from shocks; reducing price risks; reducing risks from opportunism; and raising minimum expected returns (allowing for premia needed to offset risks). Different risks may be traded off against each other and against expected returns, so that investment decisions will be made allowing for risk-return criteria across all four conditions. Effective policy will concentrate on reducing the exposure to and effects of the largest risks. In contrast to well-developed economies with rich competitive markets, where players can generally be confident that the market will provide coordination, poor rural areas with thin markets require particular attention to problems of coordination failure and price risk and, initially at least, development of non-market coordination mechanisms to reduce these risks. We therefore turn now to consider how these problems have been addressed under different recent policy regimes.

\section{POS T-IN DEPENDEN CE 'INSTIT UT I ONAL FIXES'}

Institutions have, rightly, been receiving increasing attention in development policy. New institutional economics commonly distinguishes between 'institutional arrangements' and the 'institutional environment' (Davis \& North 197I). The former refers to the means by which people attempt to overcome the challenges of transacting in a particular context, some aspects of which have been sketched above in the case of rural Malawi. The latter refers to the broader features of the transactions environment, such as the accountability of government; the extent of property rights and their enforcement; access to and reliability of different kinds of information; and the balance between laws and policies which facilitate the extraction of rents versus those which encourage competition and new investment. 'Economic coordination' sits between these two categories, as it involves private business arrangements, government action (or where not intervening, a 'government stance') and possibly collective action by businesses. The recent interest by development agencies in institutionalism (e.g. World Bank 2002) has tended to focus on the 'institutional environment' and on the importance of governance, communications infrastructure, legal systems and property rights in supporting the development of competitive markets. In contrast, new institutional economics has been able to show that institutional arrangements arise as specific responses to particular context-specific challenges in transacting and economic coordination, modified by power relations between the contracting parties. Thus analysis and evaluation of alternative 
institutional arrangements at a given stage of development raise major practical questions: where arrangements are patently unsatisfactory and could realistically be improved, do the fundamental causes of failure to improve result primarily from matters of power, of ideology, or of knowledge? Answers to such questions will often be based more on practical experience of 'what works' than on more abstract conceptual analysis.

Malawi's post-independence history provides an interesting set of examples of the interplay of these issues. For thirty years, from the early I96os to the early ig9os, Malawi pursued a broadly consistent approach to building institutional arrangements and coordination mechanisms for rural development, subsequently abandoning this for a much less interventionist approach. While power and ideology are important elements of this story, we focus on more pragmatic processes of trial and error that led to the development of institutional arrangements and coordination mechanisms within the broad ideologies and structural relations dominant in Malawi at different times during this period.

Malawi, like many other African countries, extended and deepened the system of monopolistic marketing parastatals established in the preindependence period, channelling substantial foreign aid towards investing in the parastatal infrastructure. There were strong political and economic reasons for newly independent governments establishing or continuing with and extending the activities of these parastatals. Governments needed to take action, and to be seen to take action, to promote agricultural and rural development, but the private sector was weak (as regards access to capital and human resources, and in organisational capacity), and the poor market and infrastructural development in rural areas presented highly risky and unattractive investment opportunities, as discussed above. At the same time, there was implicit recognition of the major coordination challenges facing private investors in smallholder agriculture. State intervention was seen as a means of addressing all these problems, in that it could provide a coordination mechanism across trading, infrastructural, research and extension investments and activities; it could access official finance sources; it could coordinate with farmers; and it could invest in the organisational and human resource development necessary to develop working systems. ${ }^{6}$ At the level of macroeconomic policies, government policies to fix exchange rates and control agricultural markets allowed price stabilisation and price setting to reduce price risk to farmers and to set finance, input and output prices to give risk-adjusted returns high enough to attract investments in intensified crop production, at least by better-off smallholders. Pan-territorial pricing allowed these benefits to extend even to remote rural areas. At its height, this approach led to the 
integrated rural development projects of the i970s and i98os, extending coordination into health, education and roads as well as agricultural research and extension, input supply, crop marketing and seasonal finance.

The parastatal system can therefore be seen as a specific 'institutional fix' (Kydd et al. 200I) that enabled governments to address the five investment risk trap problems identified earlier: risks from coordination failure; risks from shocks; price risks; risks from opportunism; and low expected returns. Focusing on the problems facing farmers, governments took on the task of coordinating investments to provide the financial and input and output marketing services farmers needed. By committing themselves to this task, undertaking investments themselves, and controlling and stabilising prices, government took on the risks involved in developing and delivering these services, encouraged coordinated commitment by farmers, and took over price risks from farmers. Coordination across credit provision and recovery, input supplies and crop marketing also allowed the development of mechanisms to reduce incentives for farmers to default on loans, and thus reduce risks of opportunism. This was an important basis for the very high loan repayment rates achieved in Malawi as compared, for example, with Zambia and Zimbabwe where the political economy did not take advantage of this feature of the system. ${ }^{7}$

As is well known, parastatals in Africa have a mixed record. Some have supported, at different times, large increases in maize production in more favoured maize growing areas, a growth dynamic in some rural areas, and national (though not household) food security. Where present, however, these gains were achieved at considerable cost, and parastatals were often inefficient, ineffective monopolies and state organs of patronage and agricultural taxation. In Malawi ADMARG operated for a number of years with commendable efficiency, and the Smallholder Agricultural Credit Authority maintained for many years an outstanding repayment record on farmer lending. ${ }^{8}$ However, cross subsidisation from cash crops to maize depressed smallholder cash crop production and earnings and became increasingly difficult to finance, and this led to a steady decline in its effectiveness. Direct benefits tended to accrue to better-off farmers in more favoured areas (as regards lower land pressure and more reliable climate), and by-passed more challenged rural areas where large numbers of the rural poor are located. ${ }^{9}$ The longer-run sustainability of this institutional model was also undermined by an increasing tendency to rely on state and party power to command top-down coordinated action, rather than positive incentives rooted in players' perceived self-interests.

However, these problems should not mask the institutional problems that many African parastatals addressed, nor the successes that, as in 
Malawi, they sometimes achieved in addressing these problems. In particular, their record needs to be judged against the achievements of the liberalised markets that succeeded them and to which we now turn.

\section{I B E R A L I S A T I O N}

There is an extensive literature describing the different processes of liberalisation in Malawi and its neighbours (see e.g. Chilowa 1998; Deininger \& Olinto 2000; Jayne et al. 2002; Jayne \& Jones 1997; Kherallah \& Govindan I999), and we will do no more here than describe their broad effects and relate them to the investment coordination and risk problems of poor rural areas. There continues to be considerable debate about the effects of liberalisation, largely due to difficulties (a) in establishing counterfactuals as regards the effects of alternative policies to liberalisation; (b) in agreeing how far liberalisation has been achieved, and whether continuing problems are the result of too little or too much liberalisation; and (c) in separating the effects of different elements of liberalisation and of other simultaneous changes, in, for example, national governance and international markets (Dorward et al. 2004; Jayne et al. 2002; Kherallah et al. 2000; Orr \& Mwale 200I). It is, however, generally agreed that by the late I980s the parastatal system was unsustainable, as it was becoming increasingly inefficient and ineffective, and imposed growing fiscal demands on government. By pulling back the state from commitments to carry investment, price and exchange risk, liberalisation solved some problems, removing the price distortions and operational inefficiency of state managed systems, reducing fiscal strain, and reducing scope for rent seeking. Positive developments noted in Malawi's neighbours included benefits for maize consumers from competition in maize processing, with expansion of local hammer mills and reduced transport and processing costs (Jayne \& Jones 1997), and the development of successful private institutional arrangements supporting smallholder production of certain cash crops (e.g. cotton, Gordon \& Goodland 2000).

As regards maize crop production, however, liberalisation has failed to solve the challenges of high cost and patchy service delivery. Instead these services have largely disappeared. Investment in financial and input service delivery, in produce trading, and in farm production has withered away, as private sector investment has not replaced the parastatal system that aspired to support rural investment in maize production. Not unexpectedly, rural economies are now caught in a low equilibrium trap created by systemic investment risks which render the necessary investments unattractive. Farmers face an absence of financial services and large 
uncertainty about maize prices and hence risks as regards profitability of investments in maize production. Rural financiers face problems of widespread borrower opportunism and strategic default, with limited investment opportunities for borrowers, against very high interest rates. Input traders face low effective demand, and output traders face low and uncertain supply. Consumers also face very uncertain maize prices, making it dangerous to diversify out of maize production into other more profitable farm or non-farm activities (Dorward i999; Orr \& Orr 2002). All investors also face high degrees of uncertainty from macroeconomic instability (with rapidly changing exchange rates and inflation, and high interest rates), and from often erratic government and donor policies and interventions affecting food and other markets.

It is relatively easy to identify failures in both the post-independence market intervention and the more recent market liberalisation prescriptions; a more difficult task is to chart an alternative way forward. The first step must be to identify the critical elements needed to promote productive investments and wealth creation in poor rural areas. Our analysis of systemic investment risks in these areas, and experience with market intervention and liberalisation policies, suggests that changes are needed in institutional arrangements (these changes have to be teased out of practical experience of 'what works' in facilitating transactions in poor rural areas), and in political economy and the supply of public goods. We summarise these below and expound on them in discussion in the following section:

A. Necessary changes (primarily) in institutional arrangements:

I. non-market coordination mechanisms to reduce economic coordination risks in thin markets;

2. measures to reduce investors' vulnerability to and risks from price shocks;

3. measures to reduce consumers' vulnerability to and risks from food price shocks;

4. measures to reduce investors' vulnerability to and risks from opportunism by other actors in the supply chain.

B. Necessary changes (primarily) in the political economy and the supply of public goods:

5. measures to reduce investors' vulnerability to and risks from opportunism by the state and politically powerful rent seekers; 
6. business opportunities that offer significant expected returns to investors; it has been argued elsewhere (Kydd et al. 2004) that agriculture generally offers the best prospects for stimulating broad based, poverty reducing growth in rural areas in Africa, either through increased production of tradables that bring income into the area, and/or through increased and lower cost production of non-tradable staple foods, but there are important caveats to this including, for example, technological difficulties in raising agricultural productivity in lower rainfall/lower potential areas;

7. stable and transparent policies governing macroeconomic management and government interventions in markets (including financial, food and agricultural input markets);

8. improved communications infrastructure in terms of roads and telecommunications linking rural areas to markets.

This is a long 'shopping list', but these are all necessary elements for broad based poverty reducing growth. It is striking that, with the exception of limited cash crop business opportunities in some areas, at present these elements are largely absent from poor rural areas in Malawi. Integrated rural development projects of the ig7os and early ig80s attempted to take on this ambitious agenda, but largely failed, either because they were ineffective or because they were too expensive to be sustained, and were abandoned as part of structural adjustment and liberalisation policies in the late ig8os. How can this agenda be taken up more successfully at the start of the twenty-first century?

WHERE NEXT? PRINGIPLES, POLIGIES AND AGTION

There are no simple off-the-peg answers, but four principles should guide the search for and design and implementation of effective rural development strategies:

- The fiscal costs of rural development must be set against the human, economic and financial costs of development failure, either continuing poverty and sporadic relief (with unacceptable human costs that were particularly apparent in the recent crisis but are also evident in high chronic prevalence of child malnutrition and infant mortality), or indefinite safety nets.

- Institutional innovation is needed to develop more imaginative solutions that reduce risk and promote coordination, sustainable investment, confidence and market development, addressing the twin problems of state and market failure that have each bedevilled in different ways both the market intervention and the market liberalisation approaches to development. These are very difficult problems, and we discuss below some ideas as 
to how they might be addressed. The insights from new institutional economics applied to institutional arrangements and economic coordination may be helpful here, in identifying the precise features in arrangements that cause them either to succeed or to fail.

- Policies and interventions should be designed to be flexible and to address and match the varied and changing opportunities and constraints of different areas, with different balances of emphasis between wealth creation and safety nets, and between different opportunities and different institutional mechanisms in different areas. This will involve a phased approach that seizes opportunities as they arise and is prepared to move forward fast in areas where the way forward is clearer, while acting more cautiously where problems are more intractable. Varying emphasis will also be needed on different types of technical change, and different technologies will need different types of phased institutional development (see e.g. Kydd et al. 200I).

- Policies and interventions should also be mutually consistent and long term, so that different players have time to learn how to operate in a stable economic and institutional environment, so that they have confidence that investments will yield returns in the short, medium and long term, and so that policies and interventions in different sectors and different areas do not work against each other. A particularly important issue here is that short and medium-term interventions focusing on relief and poverty alleviation should support rather than undermine longer-term policies and processes of market and wealth creation.

These principles perhaps raise more questions than they answer, with, for example, critical questions about the types of institutional innovations that could meet these challenges; about apparently intractable problems in areas where there are no apparent business opportunities to support widespread growth; and about contradictory demands for flexible policies on the one hand and stability and consistency on the other, while charting new waters in a rapidly changing world with political expediency and competition for limited resources in dealing with short-term crises. We briefly address each of these issues in turn.

As noted earlier, weaknesses in the institutional environment are increasingly prominent in discussions of development policy. Vitally important though these matters are, our earlier analysis shows that overcoming weaknesses in the institutional environment will not be enough to get markets going where there are severe problems of economic coordination risk: non-market coordination mechanisms are needed to 'kick-start' markets and economic activity (Dorward et al. 2004). The state, 
working together with other stakeholders, has a critical role to play in supporting mechanisms for coordination between investors, and in reducing investor risk and promoting investor confidence. Macroeconomic stability and a favourable institutional environment, although arguably absent from the region for much of the last twenty years or so, are important in helping to reduce some elements of investor risk and promote investor confidence. However, they do not deal centrally with the major issues of coordination, opportunism, and price risks, or of low returns to investment.

Lines of solution may be found in building on the pockets of past success with parastatals and of current success with cash crops; measures that may be able to simultaneously address coordination and opportunism risks include regulated monopolies, regional commodity franchises, trader associations and farmer associations. These may be integrated with measures that provide some form of insurance for investors and consumers against price risk. State approaches include the maintenance of grain reserves, price intervention and guarantees, and market information systems. Nonstate approaches include improvements to market infrastructure and the development of commodity exchanges and insurance markets. All of these have well-known and difficult problems related to moral hazard, adverse selection and governance; and proposals for input, maize or price subsidies have very large budgetary implications. However, there is a growing body of expertise on different ways of managing risk (e.g. Anderson 200I) and combinations of international, national and local institutions can often be crafted to reduce these problems (for example, benefits from longterm mutual commitments to different forms of 'competitive cooperation' or interlocking arrangements may provide both incentives for complementary investments and protection from opportunistic behaviour, Dorward et al. 1998). These problems can only be overcome if governments and the international community recognise and commit resources to address these issues in partnership with rural people, businesses, NGOs and civil society.

A second major difficulty is the apparently intractable problem in many high population areas in identifying profitable activities which could support widespread poverty reducing growth. In overcrowded areas in southern Malawi, for example, there are few if any agricultural activities that can provide widespread and sustained improved income opportunities. These areas were largely bypassed by the growth in maize production supported by the 'post-independence institutional fix' (although Evans \& Kydd I990 document some success in the I980s). Important though these problems are, they should not hold back action 
that will either support growth in other areas or support limited growth in these areas, as some growth is better than none, with benefits for poorer areas in (a) stimulating growth in the economy as a whole (with positive spinoffs as regards increased demand for labour, growth in the non-farm economy, and government revenues), and (b) generating experience and ideas to take forward in the more difficult areas. There is an important related question here regarding the extent to which attention should be focused on maize production and markets in its supply chain. Post-independence policies placed a strong emphasis on maize, due to the heavy reliance on and preference for maize in rural and urban diets. However, in tending to ignore root crops and millet, these policies increased reliance on maize (which is a relatively risky crop in some areas), and failed to develop technologies and marketing and information systems for other often locally important crops.

A third difficulty with the four principles we propose is the apparent contradictory demands for flexible policies on the one hand and stability and consistency on the other. How can stability be achieved in countries experimenting with policies, responding to crises rather than managing change, and vulnerable to highly uncertain natural, economic and donor policy environments? Is stability compatible with radical structural changes such as land redistribution? There are no simple answers to this, but again, a first step is to recognise the problem, and then to identify key elements for managing change. These are likely to include emphasis on transparency and on deliberative mechanisms that establish goals and rules for responding to and managing change, with checks and balances that restrain and penalise opportunistic behaviour by governments and donors (and their agents) as well as other stakeholders. Such mechanisms inevitably imply some mutual voluntary surrender of sovereignty. 'Joined up' policy formulation processes are also needed to ensure consistency across different areas, across different sectors, and across different types of policy (for example relief and development policies, as indicated earlier). There are also important questions for regional coordination here. Devereux (2002) notes that price supports and subsidies may be more problematic now than in the past, as border effects were more limited when more countries were following similar pricing policies. Better regional market and policy integration might also play an important role in reducing price risks.

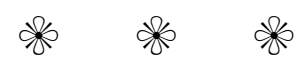

The recent food crisis in Malawi and elsewhere in central-southern Africa has drawn stark attention to the failures of development policies over the 
last forty years to create wealth and develop a robust economy, or the markets on which such an economy must depend. Market intervention and market liberalisation policies have both failed, in different ways, to address fundamental coordination problems in market development. These failures can be attributed, in part at least, to a certain degree of naivety about the weaknesses of government and of markets. Looking forward, we now have a better understanding of these weaknesses, and of ways in which they may be addressed. However, the task is in other ways more difficult than it was twenty or thirty years ago, as there is more pressure on limited natural resources, the global environment is perhaps more difficult now than it was, and there are severe challenges from decapitalisation and decline, and from the impacts of HIV/AIDS. These difficulties should not, however, be an excuse for inaction: the recent food crisis must be a stimulus to concerted and committed action to learn from the lessons of the past, and to develop and implement consistent policies that will support development of the fundamentals of a working economy. This will require long-term investment in institution building, a willingness to radically rethink current market liberalisation policies and consider costly interventions to make farming profitable, and a willingness by all stakeholders (and particularly governments and donors) to commit themselves to pragmatic partnerships that by developing trust allow them to surrender some of their sovereignty and take risks, in the hope of achieving wider gains.

\section{NOTES}

I. An earlier version of this paper was originally presented at 'Malawi after Banda: perspectives in a regional African context', a conference to mark the retirement of John McCracken, 4-5 September 2002, Centre of Commonwealth Studies, University of Stirling. The work draws on various pieces of work commissioned by the UK Department for International Development; however the findings, interpretations and conclusions expressed in this paper are entirely those of the authors and should not be attributed to the Department for International Development, which does not guarantee their accuracy and can accept no responsibility for any consequences of their use. We gratefully acknowledge helpful comments on the development and revision of this paper from colleagues in Imperial College London and from two anonymous reviewers.

2. The data reported here are taken from a variety of sources, all located in January 2004 on the World Bank website. These sources, which were not entirely mutually consistent, included: devdata.worldbank.org/idg/ and devdata.worldbank.org/CPprofile.

3. The estate sector has three main crops: tobacco, sugar and tea, with tobacco being much the most important. Tea production is limited by rainfall requirements and most suitable land is already planted. Sugar is limited by quotas into high value markets. At the beginning of the I99os, the largest sub-component of tobacco estate tobacco was burley, produced under a form of sharecropping called the 'visiting tenant system'. This depended critically on legal prohibition on smallholders (potential tenants) growing burley on their own customary land, a prohibition which was removed with the liberalisation of the early ig9os. This had the effect of transferring much of the burley industry to the smallholder sector, a highly desirable outcome in terms of income distribution, but one which severely undermined the profitability of most burley estates. The best estates could still attract good tenants, because of the relatively high incomes available. 
4. HIV/AIDS adult seroprevalence is estimated at $15 \%$, and the number of children orphaned by AIDS at 470,00o; see devdata.worldbank.org/idg/

5. The terms 'low level equilibrium trap' and 'underdevelopment equilibrium' are virtually interchangeable. Hoff (2000) gives an account of the origins of the concept, starting with Rodenstein-Rodan in 1943 and developed in the works of Nurkse, Myrdal and Hirschman. The essence of the idea is that the widespread existence of spillovers/externalities and the need for certain critical public goods means that, at the early stages of development, sustained economic growth will be very difficult to achieve without government intervention to fund public goods and undertake the necessary coordination to push the economy out of the trap. Modern formulations of low level equilibrium traps stress that they can persist and prove intractable in the face of positive individual changes such as: improved export prices, technological 'silver bullets' and 'good mutations' of current institutional arrangements.

6. In addition to these very practical problems facing private sector led agricultural development, wider political motives were very important for the development of parastatals. There was often a deep mistrust of private companies seen to be dominated by or associated with former colonial interests, and often a socialist philosophy suspicious of the private sector and of markets, with a belief in the need for the state to actively intervene to direct the economy to achieve both productive and welfare objectives. At the same time there was great confidence in the ability of the state; and economic development theories that stressed the importance of industrial sector development, and the taxation of agriculture to finance this, found state involvement in agricultural marketing activities a convenient tool for such taxation. In Malawi in particular the parastatal system was linked to the development of the autocratic one party state.

7. This success in credit was partly due to the prevailing institutional environment (i.e. the 'hard state' of President Banda) with confiscation of property of defaulters. While this was important in encouraging repayment for households facing particular crises or otherwise tempted to default for short-term gain, we hold that other aspects of the institutional arrangements themselves strongly discouraged farmers with longer-term horizons from defecting on credit contracts. These institutional arrangements included mutually guaranteeing credit groups subject to the sanction of the closure of poorly performing groups. The incentive to be a member of a group with a good credit record was not only access to finance, but also access to assistance by extension workers with the logistics of produce marketing and, more importantly, often rationed input supply.

8. By contrast the burden of subsidies, loan defaults and price controls in Zimbabwe and Zambia led to unsustainable drains on government fiscal resources, and, with increasing cash flow problems, inability to deliver effective services.

9. In Zimbabwe, for example, Natural Regions IV and $V$ were largely excluded from the benefits of the maize revolution (Poulton et al. 2002). In Malawi the Central and Northern Regions, where land pressure and poverty rates are lower, gained more from these policies than the Southern Region, where land pressure and poverty are higher.

\section{R E F E R E N C E S}

Anderson, J. R. 2001. 'Risk management in rural development: a review', Rural Strategy Background Paper No. 7. Washington, DG: World Bank.

Bryceson, D. F. 1999. 'Sub Saharan Africa betwixt and between', Working Paper, Leiden: Afrika Studiecentrum. http://asc.leidenuniv.nl.

Carr, S. J. 1997. 'A green revolution frustrated: lessons from the Malawi experience', African Crop Science foumal 5, I: $93^{-8}$.

Cavendish, W. I999. 'Poverty, inequality and environmental resources; quantitative analysis of rural households'. London: Imperial College.

Chilowa, W. 1998. 'The impact of agricultural liberalisation on food security in Malawi', Food Policy 23, 6: 553-69.

Davis, L. E. \& D. G. North. 197I. Institutional Change and American Economic Growth. Cambridge University Press.

Deininger, K. \& P. Olinto. 200o. 'Why liberalisation alone has not improved agricultural productivity in Zambia : the role of asset ownership and working capital constraints', World Bank Policy Research Working Paper Series 2302.

Devereux, S. 2002. 'The Malawi famine of 2002', IDS Bulletin 33, 4: 70-8.

Dorward, A. R. 1999. 'Farm size and productivity in Malawian smallholder agriculture', fournal of Development Studies 35, 5: I4I-6I. 
Dorward, A. R., J. Kydd \& C. Poulton, eds. I998. Smallholder Cash Crop Production under Market Liberalisation: a new institutional economics perspective. Wallingford: CAB International.

Dorward, A. R., J. Kydd, J. Morrison \& I. Urey. 2004. 'A policy agenda for pro-poor agricultural growth', World Development 32, I : 73-89.

Eicher, C. K. \& B. Kupfuma. I998. 'Zimbabwe's maize revolution: insights for closing Africa's food gap', in C. K. Eicher \& J. Staatz, eds. International Agricultural Development. Baltimore, MD: The John Hopkins University Press, 550-70.

Ellis, F., M. Kutengule \& A. Nyasulu. 2002. 'Livelihoods and rural poverty reduction in Malawi', LADDER Working Paper No. I7. Norwich: UEA.

Evans, J. \& J. Kydd. I99o. Phalombe Women's Agricultural Development Programme: a case study of a gender and poverty focused seasonal credit programme. Wye: Wye College.

Fisher, M., G. Shively \& S. Buccola. 2002. 'An empirical investigation of activity choice, labor allocation and forest use in Southern Malawi', Staff Paper \#02-OI. Purdue, IN: Dept. of Agricultural Economics, Purdue University.

Gordon, A. \& A. Goodland. 200o. 'Production credit for African small-holders: conditions for private provision', Savings and Development 24, I: 55-84.

Heisey, P. W. \& M. Smale. I996. Maize Technology in Malawi: a green revolution in the making? Mexico City: CIMMYT.

Hoff, K. 2000. 'Beyond Rosenstein-Rodan: the modern theory of underdevelopment traps', World Bank Economic Conference 2000.

Jaffee, S. \& J. Morton, eds. I995. Marketing Africa's High Value Foods. Dubuque, IA: Kendall Hunt.

Jayne, T. S., J. Govereh, A. Mwanaumo, J. Nyoro \& A. Chapoto. 2002. 'False promise or false premise? The experience of food and input market reform in eastern and southern Africa', World Development 30, II : i967-85.

Jayne, T. S. \& S. Jones. I997. 'Food marketing and pricing policy in eastern and southern Africa: a survey', World Development 25, 9: 1505-27.

Kherallah, M. \& K. Govindan. I999. 'The sequencing of agricultural market reforms in Malawi', Fournal of African Economies 8, 2: 125-51.

Kherallah, M., C. Delgado, E. Gabre-Madhin, N. Minot \& M. Johnson. 20oo. 'The road halftravelled: agricultural market reform in sub-Saharan Africa', Food Policy Report. Washington, DC: International Food Policy Research Institute.

Kydd,J. G. \& R. Christiansen. I982. 'Structural change in Malawi since independence: consequences of a development strategy based on large scale agriculture', World Development io: $355-75$.

Kydd, J. G., A. Dorward, J. Morrison, \& G. Cadisch. 2004. 'Agricultural development and pro-poor economic growth in sub-Saharan Africa', Oxford Development Studies 32, I : 37-57.

Kydd, J. G., A. Dorward \& C. Poulton. 200I. 'New institutional economics, agricultural parastatals and marketing policy', in D. Byerlee \& I. Livingstone, eds., Renewing Development in Sub-Saharan Africa: policy, performance and prospects. London: Routledge.

Mabeza-Chimedza, R. i998. 'Zimbabwe's smallholder agriculture miracle', Food Policy 23, 6: 529-37.

Morton, K. I975. Aid and Dependence: British aid to Malawi. London: ODI/Croom Helm.

Orr, A. \& B. Mwale. 200I. 'Adapting to adjustment: smallholder livelihood strategies in Southern Malawi', World Development 29, 8: I325-43.

Orr, A. \& S. Orr. 2002. 'Agriculture and micro enterprise in Malawi's rural south', Agren Network Paper IIg.

Poulton, C., R. Davies, I. Matshe \& I. Urey. 2002. 'A review of Zimbabwe's agricultural economic policies: I980-2000', Working paper, Institutions and Economic Polices for Pro-Poor Agricultural Growth. London: Imperial College.

Williamson, O. E. I985. The Economic Institutions of Capitalism. New York: The Free Press.

World Bank. 200ı. Malawi at a glance. Washington, DC: World Bank.

World Bank. 2002. World Development Report 200I/2002. Washington, DC: World Bank.

World Bank. 2003. Malawi: Poverty Reduction Strategy Paper-Progress Report Joint Staff Assessment. Washington, DC: World Bank, Io October. 